\title{
Mammary development
}

By Isabel A. Forsyth, AFRC Institute for Grassland and Animal Production, Hurley, Maidenhead, Berks SL6 5LR

The basic structure of the mammary gland is laid down in the fetus. There is an important postnatal phase of allometric development, involving duct elongation and penetration of the mammary stroma at a rate greater than increase in body size. This begins before, and in some species continues through, puberty. The mammary gland then undergoes a cycle of proliferation, differentiation, function and regression during adult reproductive life in female mammals. In eutherian mammals, development of the lobules of alveolar cells which secrete milk occurs principally during pregnancy, but growth of the gland continues into lactation, accounting for as little as $2 \%$ (sheep) or as much as $26 \%$ (goats) or $40 \%$ (rats) of total increase in DNA (see Forsyth, 1982; Tucker, 1987). The classical methodological approaches of endocrinectomy and replacement therapy have established the importance of hormones from the ovary, adrenal, pituitary gland and placenta in bringing about mammary development. More recently, in vitro methods have been devised which are suitable for the study of mammary epithelial cell proliferation, and these are revealing the influence of growth factors in controlling cell numbers. At the same time, in vivo studies emphasize the importance of nutrition in modulating mammary development.

\section{Endocrine control of postnatal mammary development: in vivo studies}

Mammary development requires the complex interplay of many hormones. Studies are most complete in rodents. In rats (Lyons, 1958) and in mice (Nandi, 1959) deprived of pituitary, adrenals and ovaries (triply-operated) appropriate hormone combinations will bring about the different phases of mammary development.

Prepubertal growth. Allometric duct growth and end bud formation are brought about in triply-operated rodents by oestrone + adrenal corticoid + growth hormone $(\mathrm{GH})$. Although beginning before puberty, allometry is abolished by ovariectomy and restored by oestrogen administration in rodents (Cowie, 1949) and in heifers (Wallace, 1953). However, in lambs, early ovariectomy influences neither mammary development nor total oestrogens in the circulation (Wallace, 1953; Johnsson, 1984). Allometric duct growth may be initiated by an interaction between ovarian hormones and $\mathrm{GH}$ secretion resulting from maturation of the hypothalamic-pituitary axis. In ovariectomized female rats, a crude pituitary extract was needed together with exogenous oestrogen to advance the onset of allometric duct growth before day 20 (Silver, 1953), while increases in circulating GH (Eden et al. 1978) and in pituitary GH responsiveness to thyrotrophin releasing hormone (TRH) (Strbák et al. 1981) occur in rats at about this time. Factors which bring about the end of allometric duct growth are not well understood.

Pregnancy and lactation. Triply-operated rodents require administration of oestrogen + progesterone + adrenal corticoid $+\mathrm{GH}+$ prolactin to mimic the lobulo-alveolar growth of pregnancy, while a similar hormone combination produces moderate udder development in hypophysectomized-ovariectomized goatlings (Cowie et al. 1966). The importance of prolactin (or a prolactin-like activity) for mammary development in goats was demonstrated by Hart \& Morant (1980), who showed that blocking prolactin secretion prevented the increase in udder size in response to oestrogen + progesterone in 
intact non-pregnant animals. In sexually immature monkeys, hypophysectomy inhibits the growth and development of the mammary gland stimulated by oestradiol, but neither prolactin nor GH was confidently identified as the pituitary factor involved (Kleinberg et al. 1985). Some of the hormonal activities involved in mammary development may originate in the placenta in pregnant females. For example, the principal source of progesterone is the placenta in the second half of pregnancy in women and sheep. In rodents, primates and ruminants, the placenta secretes placental lactogen (PL) which may substitute in part for the activities of both prolactin and GH (Forsyth, 1986). In general, it is still not clear what drives (or limits) mammary development, and there are probably wide species differences (see Forsyth, 1986; Tucker, 1987). In sheep and goats, but not cattle, there is a good temporal relationship between rising concentrations of PL and the initiation of lobulo-alveolar development. In rats and mice, the lower molecular weight PL II may play this role (Thordarson \& Talamantes, 1988), while in pigs PL appears not to be present and rising oestrogen concentrations coincide with development of the mammary gland (Buttle, 1988).

\section{In vitro methods to study mammary development}

Much has been learned from in vivo experiments, but they are possible in only relatively few species. Moreover, they cannot determine whether hormones act directly or indirectly on growth of mammary epithelia. Useful results have been obtained from mammary transplants in nude mice (Sheffield \& Welsch, 1986) and by local injection or implantation of hormones (Silberstein \& Daniel, 1987), but suitable in vitro methods should enable direct effects on cells and cell-cell interactions to be studied.

The culture of explants of mammary tissues (Dils \& Forsyth, 1981) has been widely used to study the direct effects of hormones on the synthesis of milk constituents by mammary tissue, but it is of more limited value in studying mammary growth. Essentially only one round of cell division occurs. An alternative approach is to culture whole glands, within the mammary fat pad, retaining the normal relationship between epithelium and stroma (Ichinose \& Nandi, 1966; Wood et al. 1975). However, whole organ culture is applicable only to thin flat glands, such as those of small rodents, and is dependent on in vivo hormonal priming of the donor animal, so that the carry-over of in vivo influences is clearly involved in the in vitro response. The use of rat tail collagen as a substratum (Emerman \& Pitelka, 1977) has opened up new possibilities. The control of sustained proliferation can be studied in normal mammary epithelial cells grown on attached collagen gels (Mackenzie et al. 1982) or embedded within collagen when branched tubular structures form (Yang et al. 1980; Imagawa et al. 1982; McGrath, 1987).

In studying mammary development in vitro, a further necessity has been the development of serum-free media. For many years, serum has been added to culture media to sustain growth of cells, but the essential components of this undefined supplementation were unknown. Several approaches have now contributed to reducing or eliminating the need for serum or tissue extracts, or both. The nutrient requirements for particular cell types can be optimized, the concept of cellular nutrition (Bettgar \& McKeehan, 1986). Sato (see Barnes \& Sato, 1980) developed the hypothesis that multiple factors present in serum are responsible for its growth stimulatory properties and that these can be identified and added. Attention was first focused on hormones and growth factors, but other non-hormonal components of importance which serum can provide include supplementary nutrients, binding and transport proteins and factors which promote the attachment and spreading of cultured cells. Routine additions to synthetic culture media have also to be examined critically. It has recently been realized 
that phenol red, which is widely used as a $\mathrm{pH}$ indicator, acts as a weak oestrogen and can mimic or mask the effect of added oestrogens on cultured cells (Berthois et al. 1986).

We have been able to study DNA synthesis in ruminant mammary cells in primary culture using a very simple serum-free system of Medium 199 with Earle's modified salts, supplemented with Hepes to maintain $\mathrm{pH}$, additional acetate (to $5 \mathrm{~mm}$ ) for fatty acid synthesis, and bovine serum albumin treated to remove lipid, steroids and growth factors. Fibronectin is added for the first $18 \mathrm{~h}$ of culture to promote cell attachment (Winder \& Forsyth, 1986).

\section{Hormonal control of epithelial cell proliferation}

Classic mammogenic hormones. Mammary cells contain receptors for oestradiol, progesterone, glucocorticoids, thyroid hormone and prolactin, but not apparently for GH (see Forsyth, 1983; Akers, 1985). They also respond in vitro to prolactin and glucocorticoid in the presence of insulin, and modified in some instances by thyroid hormone (Topper \& Freeman, 1980), by synthesizing milk products. However, classic mammogenic hormones have in general little effect on proliferation, although (see above) this conclusion will need to be modified in the case of oestradiol. Stockdale $e t$ al. (1966) showed that insulin was a sufficient and necessary stimulus for DNA synthesis in mammary explants from adult virgin and mid-pregnant mice in phenol red-containing medium. This observation has been confirmed many times and shown for other species (e.g., goat, Skarda et al. 1977). The addition of prolactin and adrenal corticoids to culture media at best enhances or extends in time the mitogenic effect of insulin.

Somatomedins or insulin-like growth factors (IGFs). Several considerations have suggested the probability of a role of IGF-1 in mammary growth. It is a structural homologue of insulin and induces mitosis in many cell types. Both IGF-1 and its major serum carrier protein are GH-dependent. Receptors for IGF-1 (type I receptors) have been detected in bovine (Campbell \& Baumrucker, 1986) and ovine (Winder \& Forsyth, 1987) mammary gland, while GH receptors apparently do not occur. The type I receptor is structurally homologous to the insulin receptor and binds insulin, but has an affinity at least 100 -fold higher for IGF-1. It is probable that the mitogenic effects of supraphysiological concentrations of insulin are mediated by this receptor. In sheep mammary cells, IGF-1 stimulates DNA synthesis, showing a classic sigmoid dose-response relationship over the dose range $1-100 \mathrm{ng} / \mathrm{ml}$, and does not appear to require the presence of any other mitogen to produce this effect, at least in phenol-red containing medium (Winder \& Forsyth, 1986). Mouse mammary epithelial cells grown in collagen gels respond to IGF-1 with an increase in cell number, but require the presence of epidermal growth factor in addition (Imagawa et al. 1986). Similarly, Furlanetto \& DiCarlo (1984) have demonstrated stimulation of DNA synthesis by IGF-1 in four human breast cancer cell lines and also the presence of type I IGF receptors.

Human breast cancer cell lines synthesize and secrete IGF-1 as judged by radioimmunoassay, partial purification and the presence of messenger RNAs (see Dickson \& Lippman, 1987). In MCF-7 cells, IGF-1 production is stimulated by oestradiol or insulin in phenol red-free medium (Dickson \& Lippman, 1987).

Although at supraphysiological concentrations insulin may act through the type I receptor, it may have important actions, acting through its own receptor. Insulin receptors have been demonstrated in mammary tissue (Campbell et al. 1987), and in ovine mammary cells we have found insulin to stimulate DNA synthesis even at concentrations as low as $10 \mathrm{pg} / \mathrm{ml}$ (S. J. Winder and I. A. Forsyth, unpublished results). Moreover, insulin cannot be effectively replaced by either epidermal growth factor 
(EGF) or IGF-1 (Bolander et al. 1981) in hormone combinations which stimulate secretory activity by mouse mammary tissue in vitro.

$E G F$. Turkington (1969) demonstrated an effect of physiological concentrations of EGF on DNA synthesis in explants of mouse mammary tumours. In cultures of whole mouse mammary glands EGF is needed to sustain a second round of lobulo-alveolar growth (Tonelli \& Sorof, 1980). In cell cultures EGF has little mitogenic effect alone, but stimulates the growth of mouse (Imagawa et al. 1986) and human (Stoker et al. 1976; Taylor-Papadimitriou et al. 1977) mammary epithelial cells when in the presence of other factors which have included insulin, cholera toxin (to raise intracellular cyclic AMP concentrations) and fibroblast feeder layers. Mice without submaxilliary glands (a major source of EGF in this species) have impaired mammary growth and a reduced ability to raise large litters (Okamoto \& Oka, 1984).

Conditioned medium from human breast cancer cell lines contains activity related to transforming growth factor- $\alpha$ (TGF- $\alpha$ ). This growth factor acts via the EGF receptor, and the receptor has also been detected in rodent and human mammary tumours and cell lines (see Dickson \& Lippman, 1987).

Other growth factors. Many breast cancer cell lines secrete an activity related to platelet derived growth factor (PDGF) although they appear not to contain a PDGF receptor (Dickson \& Lippman, 1987). PDGF is the major growth factor in serum and is a potent mitogen for mesenchymal cells (Deuel et al. 1987). Its actions, if any, in the mammary gland are, therefore, presumably paracrine on stroma.

Not all growth factors are stimulatory. Breast cancer cell lines contain a receptor for, and secrete an activity related to, transforming growth factor- $\beta$ (TGF- $\beta$ ) (Dickson \& Lippman, 1987). Fibroblastic cells are stimulated to grow by TGF- $\beta$, possibly indirectly through production of PDGF-like activity, but proliferation of epithelial cells is inhibited by TGF- $\beta$ (Moses et al. 1987). Another unrelated polypeptide growth inhibitor has been isolated from bovine mammary gland (Böhmer et al. 1987).

Growth factors in milk. High concentrations of polypeptide growth factors have been identified in the colostrum of milk of several species, including humans, mice, ruminants and pigs. Activities detected include EGF as the major mitogen in human and mouse milk (Carpenter, 1980; Beardmore \& Richards, 1983), PDGF-like activity in ruminant milk (Brown \& Blakeley, 1984), but also IGF-1 and a variety of so far only partly characterized activities (Cera et al. 1987). While in general actions on the neonatal gut are suspected, these activities may also be of importance in relation to mammary development.

\section{Nutrition and mammary development}

Nutrition can potentially affect mammary development, both directly if the energy and protein costs of development are not met, and indirectly via altering the rates of secretion of mammogenic hormones. Bauman \& Currie (1980) have described as homeorhesis the co-ordination of metabolism in various tissues to support an altered physiological state, such as pregnancy or lactation. Both overnutrition and underfeeding can impair mammary development.

Prepubertal nutrition. Attention has been focused on the importance of nutrition in prepubertal animals, by the observation that milk yield in the first lactation can be markedly depressed in dairy heifers which are reared rapidly on high levels of energy intake to reduce the age at which puberty is attained, and that this effect can persist over several lactations (Little \& Kay, 1979). The concept remains controversial, with various confounding factors needing to be considered (for review, see Johnsson, 1988). The relationship between first-lactation yield and rearing rate before puberty is curvilinear, 
such that milk yields are reduced by rates of daily body weight gain either less or greater than an optimum (about $0.7 \mathrm{~kg} / \mathrm{d}$ in Red Danish or British Friesian heifers). Both growth of the mammary fat pad (positively related to rearing rate and setting a limit on mammary gland size) and penetration of the fat pad by mammary parenchyma are involved.

The hormone most clearly implicated in linking nutrition to early mammary development is GH. Plasma GH concentrations are depressed in rapidly-reared heifers before puberty and in ad lib.- compared with restricted-fed female lambs. Moreover, administration of GH stimulates prepubertal mammogenesis in rapidly growing heifers and lambs (for references, see Johnsson, 1988). Prepubertal nutrition affects mammary development in rats, as well as ruminants, so this may be a more general phenomenon.

Pregnancy. Underfeeding in pregnancy can have marked effects on mammary development. In rats given $50 \%$ of normal food intake from day 5 of pregnancy, mammary DNA was only $70 \%$ of controls (Rosso et al. 1981). In ruminants, rapid development of both fetus and mammary gland occurs in the second half of pregnancy. In ewes, the growth rate of the mammary gland is reduced in underfed ewes carrying both single and twin fetuses (Rattray et al. 1974; Mellor \& Murray, 1985); nevertheless udder size continues to increase throughout the last third of pregnancy. Indeed, in the study of Mellor \& Murray (1985) the largest increase in udder weight in the last $5 \mathrm{~d}$ of pregnancy occurred in underfed ewes (Mellor $e$ t al. 1987), associated with an increase in the GH:insulin ratio.

It is tempting to link effects on mammary growth with GH-dependent IGF-1. At present no direct information is available. However, total IGF-1 concentrations in the plasma of ruminants are known to be increased by $\mathrm{GH}$ administration in lactating cows (Davis $e t$ al. 1987) and reduced by underfeeding (Breier $e t$ al. 1986). In rats and man, IGF-1 is also regulated by GH and nutrition (Underwood et al. 1986).

\section{REFERENCES}

Akers, R. M. (1985). Journal of Dairy Science 68, 501-519.

Barnes, D. \& Sato, G. (1980). Analytical Biochemistry 102, 255-270.

Bauman, D. E. \& Currie, W. B. (1980). Journal of Dairy Science 63, 1514-1529.

Beardmore, J. M. \& Richards, R. C. (1983). Journal of Endocrinology 96, 287-292.

Berthois, Y., Katzenellenbogen, J. A. \& Katzenellenbogen, B. S. (1986). Proceedings of the National Academy of Sciences, USA 83, 2496-2500.

Bettgar, W. J. \& McKeehan, W. L. (1986). Physiological Reviews 66, 1-35.

Böhmer, F-D., Sun, Q., Pepperle, M., Muller, T., Eriksson, U., Wang, J. L. \& Grosse, R. (1987). Biochemical and Biophysical Research Communications 148, 1425-1431.

Bolander, F. F., Nicholas, K. R., Van Wyk, J. J. \& Topper, Y. J. (1981). Proceedings of the National Academy of Sciences, USA 78, 5682-5684.

Breier, B. H., Bass, J. J., Butler, J. H. \& Gluckman, P. D. (1986). Journal of Endocrinology 111, 209-215.

Brown, K. D. \& Blakeley, D. M. (1984). Biochemical Journal 219, 609-617.

Buttle, H. L. (1988). Journal of Endocrinology 118, 41-45.

Campbell, P. G. \& Baumrucker, C. R. (1986). Journal of Dairy Science 69, Suppl. 1, 218G (abstr.).

Campbell, P. G., Frey, D. M. \& Baumrucker, C. R. (1987). Comparative Biochemistry and Physiology 87B, 649-653.

Carpenter, G. (1980). Science 210, 198-199.

Cera, K., Mahan, D. C. \& Simmen, F. A. (1987). Journal of Animal Science 15, 1149-1159.

Cowie, A. T. (1949). Journal of Endocrinology 6, 145-157.

Cowie, A. T., Tindal, J. S. \& Yokoyama, A. (1966). Joumal of Endocrinology 34, 185-195.

Davis, S. R., Gluckman, P. D., Hart, I. C. \& Henderson, H. V. (1987). Journal of Endocrinology 114, 17-26.

Deuel, T. F., Pierce, G. F., Yeh, H.-J., Shawver, L. K., Milner, P. G. \& Kimura, A. (1987). Journal of Cellular Physiology Suppl. 5, 95-99. 
Dickson, R. B. \& Lippman, M. E. (1987). Endocrine Reviews 8, 29-43.

Dils, R. \& Forsyth, I. A. (1981). Methods in Enzymology 72, 724-742.

Eden, S., Albertsson-Wikland, K. \& Isaksson, O. (1978). Acta Endocrinologica 88, 676-690.

Emerman, J. T. \& Pitelka, D. R. (1977). In Vitro 13, 316-328.

Forsyth, I. A. (1982). Oxford Reviews of Reproductive Biology 4, 47-85.

Forsyth, I. A. (1983). In Biochemistry of Lactation, pp. 309-349 [T. B. Mepham, editor]. Amsterdam: Elsevier.

Forsyth, I. A. (1986). Journal of Dairy Science 69, 886-903.

Furlanetto, R. W. \& DiCarlo, J. N. (1984). Cancer Research 44, 2122-2128.

Hart, I. C. \& Morant, S. (1980). Journal of Endocrinology 84, 343-351.

Ichinose, R. R. \& Nandi, S. (1966). Journal of Endocrinology 35, 331-340.

Imagawa, W., Spencer, E. M., Larson, L. \& Nandi, S. (1986). Endocrinology 119, 2695-2699.

Imagawa, W.. Tomooka, Y. \& Nandi, S. (1982). Proceedings of the National Academy of Sciences, USA 79, 4074-4077.

Johnsson, I. D. (1984). Nutritional and hormonal influences on prepubertal mammogenesis in sheep and rats. PhD Thesis, University of Reading.

Johnsson, I. D. (1988). In Nutrition and Lactation in the Dairy Cow, pp. 171-192 [P. C. Garnsworthy, editor]. London: Butterworths.

Kleinberg, D. L., Niemann, W., Flamm, E., Cooper, P., Babitsky, G. \& Valensi, Q. (1985). Journal of Clinical Investigation 75, 1943-1950.

Little, W. \& Kay, R. M. (1979). Animal Production 29, 131-142.

Lyons, W. R. (1958). Proceedings of the Royal Society of London 149B, 303-325.

McGrath, M. F. (1987). Journal of Dairy Science 70, 1967-1980.

Mackenzie, D. D. S., Forsyth, I. A., Brooker, B. E. \& Turvey, A. (1982). Tissue and Cell 14, $231-241$.

Mellor, D. J., Flint, D. J., Vernon, R. G. \& Forsyth, I. A. (1987). Quarterly Journal of Experimental Physiology 72, 345-356.

Mellor, D. J. \& Murray, L. (1985). Research in Veterinary Science 39, 230-234.

Moses, H. L., Coffey, R. J., Leof, E. B., Lyons, R. M. \& Keski-Oja, J. (1987). Journal of Cellular Physiology Suppl. 5, 1-7.

Nandi, S. (1959). University of California Publications in Zoology 65, 1-128.

Okamoto, S. \& Oka, T. (1984). Proceedings of the National Academy of Sciences, USA 81, 6059-6063.

Rattray, P. V., Garrett, W. N., East, N. E. \& Hinman, N. (1974). Journal of Animal Science 38, $613-626$.

Rosso, P., Keyou, G., Bassi, J. A. \& Slusser, W. M. (1981). Journal of Nutrition 111, 1937-1941.

Sheffield, L. G. \& Welsch, C. W. (1986). Journal of Dairy Science 69, 1141-1147.

Silberstein, G. B. \& Daniel, C. W. (1987). Journal of Dairy Science 70, 1981-1990.

Silver, M. (1953). Journal of Endocrinology 10, 35-45.

Škarda, J., Urbanová, E. \& Bílek, J. (1977). Endocrinologia Experimentalis 11, 105-113.

Stockdale, F. E., Juergens, W. G. \& Topper, Y. J. (1966). Developmental Biology 13, 266-281.

Stoker, M. P. G., Pigott, D. \& Taylor-Papadimitriou, J. (1976). Nature 264, 764-767.

Strbák, V., Jurčovičová, J. \& Vigaš, M. (1981). Endocrinologia Experimentalis 15, 245-249.

Taylor-Papadimitriou, J., Shearer, M. \& Stoker, M. G. P. (1977). International Journal of Cancer 20, $903-908$.

Thordarson, G. \& Talamantes, F. (1988). In The Mammary Gland, Development, Regulation and Function, [M. C. Neville and C. W. Daniel, editors]. New York: Plenum Press.

Tonelli, Q. J. \& Sorof, S. (1980). Nature 285, 250-252.

Topper, Y. J. \& Freeman, C. S. (1980). Physiological Reviews 60, 1049-1106.

Tucker, H. A. (1987). Journal of Dairy Science 70, 1958-1966.

Turkington, R. W. (1969). Cancer Research 29, 1457-1458.

Underwood, L. E., Clemmons, D. R., Maes, M., D’Ercole, A. T. \& Ketelsleger, J. M. (1986). Hormone Research 24, 166-176.

Wallace, C. (1953). Journal of Agricultural Science, Cambridge 43, 413-421.

Winder, S. J. \& Forsyth, I. A. (1986). Journal of Endocrinology 108, Suppl. 141 (abstr.).

Winder, S. J. \& Forsyth, I. A. (1987). Journal of Endocrinology 112, Suppl. 64 (abstr.).

Wood, B. G., Washburn, L. L., Mukherjee, A. S. \& Banerjee, M. R. (1975). Journal of Endocrinology 65, $1-6$.

Yang, J., Richards, J., Guzman, R., Imagawa, W. \& Nandi, S. (1980). Proceedings of the National Academy of Sciences, USA 77, 2088-2092.

\section{Printed in Great Britain}

